\title{
DUKUNGAN KELUARGA BESAR (EXTENDEED FAMILY) TERHADAP PERILAKU SEKSUAL WANITA PRA KONSEPSI DI KELURAHAN PESURUNGAN LOR KECAMATAN MARGADANA KOTA TEGAL
}

\author{
Seventina Nurul Hidayah ${ }^{1}$, Nora Rahmanindar ${ }^{2}$ \\ e-mail : seventinanurulhidayah@gmail.com \\ 1,2 Program Studi D III Kebidanan Politeknik Harapan Bersama \\ Jl.Mataram no.09 Pesurungan Lor Kota Tegal
}

\begin{abstract}
Abstrak
Dukungan dari keluarga adalah tindakan yang dilakukan untuk memudahkan aktivitas antar anggota keluarga sehingga memberikan kenyamanan. Terbentuknya keluarga besar membuat pengalihfungsian ruang yang kurang layak sehingga menimbulkan aktivitas tidak dilakukan pada ruangan semestinya. Wanita pra konsepsi yang akan mempersiapkan kehamilannya, hubungan seks yang berkualitas sangat dibutuhkan. Perilaku seksual berkualitas tepat dilakukan ditempat pribadi saat berhubungan intim. Apabila wanita pra konsepsi tinggal dalam keluarga besar akan mengurangi privasi dan membuat hasrat bercinta menurun, efek terburuknya hubungan pasangan suami istri jauh dari kata mesra dan manfaat seks yang didapatkan oleh wanita pra konsepsi yang akan memberikan kesiapan dalam menghadapi kehamilan menjadi terhambat. Tujuan penelitian untuk mengetahui dukungan keluarga besar (extendeed family) terhadap perilaku seksual wanita pra konsepsi.Penelitian ini bersifat kualitatif dengan metode dskriptif. Pengumpulan data diperoleh dari wwancara mendalam sesuai dengan pedoman wawancara. Hasil wawancara direkam dan dibuat catatan lapangan. Untuk menghindari subyektifitas, peneliti menggunakan teknik triangulasi sumber. Hasil penelitian didapatkan bahwa keluarga memberikan dukungan terhadap perilaku seks wanita pra konsepsi namun ketidaknyamanan hubungan seksual masih dirasakan wanita pra konsepsi, mereka mengalami kesulitan dalam memaksimalkan tahapan seksual selama tinggal dalam keluarga besar karena privasi kurang terjaga. Informasi ini bisa menjadi acuan bagi tenaga kesehatan dalam memberikan konseling perilaku seksual yang sehat.
\end{abstract}

Kata Kunci: Perilaku Seksual, Wanita Pra konsepsi dalam Keluarga Besar (extendeed family)

\section{Pendahuluan}

Terbentuknya keluarga besar (extendeed family) di pemukiman kumuh menimbulkan pemanfaatan ruang yang dialihfungsikan tidak semestinya sehingga kurang layak untuk digunakan terutama ruang kamar memiliki penampilan yang jorok. Kondisi tersebut membuat penghuni hidup berdesakan di ruang yang sempit dengan banyak penghuni yang lain sehingga dapat meruntuhkan tembok rahasia di antara penghuni. Penghuni akan mengalami kesusahan dalammenutupi masalah keluarga seperti perselisihan antar penghuni rumah, menjadi rentan tertular penyakit dan kurangnya privasi seksual suami istri ${ }^{[1]}$.

Berdasarkan data Disperkim (Dinas Perumahan Rakyat dan Pemukiman) wilayah Kota Tegal terdapat sebelas Kelurahan yang termasuk kawasan pemukiman kumuh diantaranya adalah Kelurahan seluas 15 ha yaitu Kelurahan Pesurungan Lor Kota Tegal. Kelurahan Pesurungan Lor memiliki tipologi pemukiman kumuh daerah pasang surut karena tergenang air pasang surut rob dengan luas lahan 100 ha.

Penambahan ruang serta bangunan yang asal jadi, akibatnya kondisi rumah secara fisik semakin terlihat acak-acakan, dan penampilan jorok. Kondisi tersebut dimana setiap penghuni harus hidup berdesakdesakan di ruang yang sempit dengan banyak penghuni yang lain dapat meruntuhkan tembok rahasia di antara penghuni. Penghuni akan mengalami kesusahan dalammenutupi masalah keluarga seperti pertengkaran anggota keluarga, menjadi rentan tertular penyakit bahkan dapat mempengaruhi perilaku seksual suami istri $^{[2]}$.

Perilaku seksual adalah tingkah laku yang didorong karena adanya hasrat seksual. Seks memiliki manfaat yang sangat banyak untuk kesehatan diantaranya adalah meningkatkan imunitas, menjaga kondisi jantung, menurunkan tekanan darah, dan membuat tidur lebih nyenyak. Manfaat tersebut dapat diperoleh dengan melakukan hubungan seks yang berkualitas ${ }^{[3]}$. 
Masa wanita pra konsepsi adalah sebelum hamil, dikatakan wanita yang telah dewasa dan siap menjadi seorang ibu $^{[4]}$.

Dalam mempersiapkan kehamilannya wanita pra konsepsi sangat membutuhkan hubungan seks yang berkualitas. Perilaku seksual yang sehat dan berkualitas sangat tepat dilakukan ditempat pribadi. Tempat yang nyaman dan dapat membangkitkan suasana hati dapat mempengaruhi kondisi hubungan intim. Apabila wanita pra konsepsi tinggal dalam keluarga besar, perilaku seksual yang berkualitas kemungkinan besar akan susah didapatkan $^{[5]}$.

Dukungan keluarga adalah bentuk pemberian dukungan pada permasalahan antar anggota keluarga yaitu memberikan dukungan pemeliharaan, emosional untuk mencapai kesejahteraan psikososia ${ }^{[6]}$.

Dukungan keluarga memiliki 4 macam bentuk antara lain Dukungan informasional, penilaian, instrumental dan emosional ${ }^{[7]}$.

\section{Metode Penelitian}

Penelitian dilakukan di rumah responden yaitu keluarga wanita pra konsepsi sebanyak 2 orang pada bulan November sampai bulan Desember tahun 2017. Penelitian ini bersifat kualitatif dengan menggunakan metode deskriptif. Sampel diambil secara purposive sampling, yang disesuaikan dengan tujuan dan jenis penelitian. Sampel penelitian yaitu informan utama dan informan triangulasi. Sebagai informan utama yaitu anggota keluarga wanita pra konsepsi yang tinggal dalam keluarga besar di Kelurahan Pesurungan Lor Kota Tegal sebanyak 2 orang. Sedangkan informan triangulasi dalam penelitian ini adalah wanita pra konsepsi yang tinggal dengan responden sebanyak masing-masing 1 orang/responden. Dalam penelitian ini jumlah sampel ditentukan oleh tersaturasinya sumber informan.iperoleh dengan melakukan wawancara mendalam sesuai dengan pedoman wawancara. Hasil wawancara direkam dan dibuat catatan lapangan. Untuk menghindari subyektifitas, peneliti menggunakan teknik triangulasi sumber.

\section{Hasil dan Pembahasan}

Penelitian dilaksanakan pada tanggal 5 6 Januari 2018 dengan menggunakan wawancara, jumlah responden yang diteliti ada 2 orang yaitu wanita pra konsepsi yang tinggal di lokasi pemukiman kumuh Kelurahan Pesurungan Lor Kota Tegal, kemudian peneliti melakukan pendekatan yang bertujuan memberikan penjelasan mengenai maksud serta tujuandan melakukan infom consent atau meminta persetujuan untuk menjadi responden sesuai dengan kriteria serta mengatur kesepakatan waktu untuk melakukan wawancara mendalam yang dilakukan sebagai mana tertera pada table.

Tabel 1. Jadwal waktu dan tempat pelaksanaan wawancara mendalam

\begin{tabular}{cccc}
\hline No & R & Waktu & Tempat \\
\hline 1 & 1 & 5 Januari 2018 & Rumah R1 \\
\hline 2 & 2 & 6 Januari 2018 & Rumah R2 \\
\hline
\end{tabular}

Dari keempat responden dilakukan pengambilan data dengan langkah-langkah sebagai berikut yaitu wawancara. Wawancara dilakukan di rumah responden dan dilaksanakan berdasarkan topic yang ditanyakan yaitu mengenai perilau seksual. Hasil wawancara ditulis secara lengkap berdasarkan hasil rekaman dengan menggunakan handphone dengan memory 4 $\mathrm{Gb}$ dan catatan kecil peneliti. Kemudian hasil rekaman tersebut akan didokumentasikan dalam sebuah CD.

a. Dukungan keluarga berupa Informasional

Bentuk dukungan informasional adalah nasehat, usulan, petunjuk dan pemberian informasi. Sebagian besar keluarga selalu memberikan nasehat kepada wanita pra konsepsi berupa : informasi persiapan kehamilan dan banyak berdoa supaya cepat dikasih momongan.

Seperti yang disampaikan oleh Responden 2 "informasi tentang dari baca-baca buku mba....dari temen2 juga....keluarga juga menyampaikan bahwa banyak2 berdoa, kasih tau juga cara biar cepet dapat momongan. Tahapan seks apa ya mbaa....hehe....ya biasanya ciuman dulu, terus biasanya 
meraba-raba gitu...nanti baru dimasukin...

b. Dukungan keluarga berupa penilaian

Sebagian besar keluarga memberikan penghargaan kepada wanita pra konsepsi dalam mempersiapkan kehamilannya dengan cara memberikan kesempatan kepada wanita pra konsepsi dan pasangannya untuk mengekspresikan dan mengungkapkan kasih sayang nya terutama dalam melakukan hubungan seksual yang berkualitas. Sesuai dengan yang disampaikan responden 1 " seks disini nggak nyaman, tapi karena sudah terbiasa kadang dibuat enak aja....keluarga juga ndukung sebenarnya mbebasin aja walaupun pengennya ya pasti kalo lagi hubungan kaya gitu di tempat yang bersih, nyaman, ga rame, jadi bisa bebas kalo kata mbaknya ada tahapan nya biar bisa semua...saya taunya seks ya buat anak aja...kalo dampak untuk kesehatannya ga paham...

c. Dukungan keluarga berupa instrumental

Dalam dukungan instrumental sebagian keluarga telah memberikan dukungan kepada anggota keluarganya terutama wanita pra konsepsi dengan baik dan positif, keluarga mampu melakukan perannya sebagai keluarga dengan baik. Bentuk dukungan tersebut yaitu : kerjasama baik dalam melakukan aktifitas rumah supaya wanita pra konsepsi tidak merasa terlalu capek, berbagi tugas dalam memasak dan mendukung makanan yang bergizi walaupun seadanya, serta memfasilitasi tempat yang lebih longgar bagi wanita pra konsepsi dan pasangannya walaupun kondisi rumah masih terkesan berdesakdesakan.

Seperti yang diutarakan dari responden 2

"disini kan rame...jadi kalo ngerjain tugas rumah ya dibagi biar ga capek...tapi saling bantu juga ...kondisi memang kurang nyaman, disini kan rame berantakan...kamar cuma 2..sempit juga....kalo yang dipengenin ya yang luas bersih, ga rame biar ada privasinya...".

d. Dukungan keluarga berupa emosional
Secara emosional, dukungan dari keluarga menunjukkan hal yang positif dan baik. Setiap keluarga memberikan dukungan yang membuat wanita pra konsepsi selama tinggal dalam extendeed family (keluarga besar) tidak merasa sungkan terutama dalam perilaku seksualnya. Seperti apa yang disampaikan responden 2 "hubungan seks setelah menikah baik-baik aja mba...dorongan seksual ya kadang pengen kadang enggak...tapi kalo dipancing2 ya pengen...hehehe....tergantung mood nya ya mba....Cuma ya liat sikon...kan disini rame...jadi seringnya malem....walaupun lama-lama juga kita biasa aja ga merasa sungkan"

Dari pemaparan di atas, hasil penelitian ini didapatkan bahwa dukungan keluarga terhadap perilaku seks wanita pra konsepsi baik secara informasional, penilaian, instrumental di Kelurahan Pesurungan Lor menunjukkan dukungan yang baik. Dukungan dan perhatian dari keluarga terutama dalam hal yang berkaitan dengan persiapan kehamilan yaitu salah satunya proses hubungan antara wanita pra konsepsi dengan pasangannya diupayakan bisa berkualitas walaupun tinggal dalam keluarga besar (extendeed family).

Sebagaimana penelitian yang dilakukan oleh Julia Oktalia dan Herizasyam tahun 2016 bahwa faktor yang berhubungan dengan kesiapan ibu menghadapi proses kehamilan. Keadaan yang kurang saat pra konsepsi mendukung kondisi yang berdampak kurang baik pula pembentukan potensi bawaan anak pada saat terjadi konsepsi yang menyebabkan pertumbuhan dan perkembangan potensi bawaan menjadi tidak optimal selama proses kehamilan. Salah satu faktor yang dapat membentu kesiapan ibu dalam mempersiapkan kehamilannya adalah dukungan keluarga.

\section{Kesimpulan}

Hasil penelitian menunjukkan bahwa Tema yang dikaji pada informan utama yaitu penyesuaian dengan penambahan anggota keluarga, dukungan terhadap 
perilaku seks wanita pra konsepsi yang menjadi bagian anggota keluarganya. Dukungan keluarga terhadap wanita pra konsepsi dalam mengoptimalkan perilaku seksualnya sebagai persiapan kualitas kehamilan dan kesehatan yang baik sudah positif. Keluarga memberikan dukungan semampunya dengan kondisi rumah yang minimalis di keluarga besar (extendeed family). Namun dari hasil wawancara dengan informan triangulasi yaitu wanita pra konsepsi menyatakan masih kurang nyaman karena kondisi rumah yang kurang mendukung privasi untuk terjaga dengan sepenuhnya.

Saran bagi tenaga kesehatan yaitu informasi ini dapat dijadikan acuan bagi tenaga kesehatan dalam memberikan konseling perilaku seksual yang sehat dan bagi pemerintah dapat digunakan sebagai bahan evaluasi keberhasilan program kota tanpa kumuh, sehingga pemerintah dapat memberikan hunian yang nyaman terutama bagi wanita pra konsepsi di pemukiman kumuh.

\section{Daftar Pustaka}

[1] Rindarjono, Gamal. 2010. Pengembangan Permukiman Kumuh Kota Semarang Tahun 1980-2006. Disertasi. Yogyakarta: Universitas Gadjah Mada.

[2] Oktalia, Juli dkk. 2016. Kesiapan Ibu menghadapi Kehamilan dan faktorfaktor yang mempengaruhinya. Skripsi. Jakarta Timur : Poltekkes Kemenkes Jakarta III

[3] Sarwono. 2010. Ilmu Kebidanan. Jakarta: Yayasan Bina Pustaka

[4] Almatsier, S. 2009. Prinsip Dasar Ilmu Gizi. Jakarta: PT Gramedia Pustaka

[5] Mu'tadin. 2012. “Aspek - Aspek Kemandirian", www.psychologymania.com/ aspek - aspek kemandirian/. Diakses 17 September 2017, pukul 21.15

[6] Potter Perry. 2009. Fundamental of nursing, Buku 1. Edisi : 7. Jakarta: Salemba Medika.
[7] Setiadi. 2008. Konsep dan Keperawatan Keluarga. Yogyakarta. Graha Ilmu. 
